\title{
Keefektifan Model Pembelajaran Role Playing Terhadap Peningkatan Interaksi Sosial Siswa Kelas 4 SDN Bumiayu 2 Malang
}

\author{
Aldy Ferdiyansyah*, Siti Latifa Zahara, Wahyu Puji Rahayu, Muhammad Alfan, Shirly \\ Rizki Kusumaningrum
}

Universitas Negeri Malang, Jl. Semarang No. 5 Malang, Jawa Timur, Indonesia

*Penulis korespondensi, Surel: aldy.ferdiyansyah.2121038@students.um.ac.id

Paper received: 2-11-2021; revised: 17-11-2021; accepted: 23-11-2021

\begin{abstract}
This research was conducted with the aim of testing effectiveness using the role playing learning model on increasing the social interaction of 4th graders at SDN Bumiayu 2 Malang. This study uses a pre-experimental design method with a quantitative approach. The results of the calculation of the paired sample test show a significance value of 0.000 which is less than 0.05 . So that it can be interpreted that there is a significant difference between the results of the pretest and posttest, in other words the use of role playing models has an effect on increasing students' social interactions. The level of effectiveness of the use of the role playing model is included in the medium category based on the results of the $\mathrm{N}$-Gain test with an average gain score of 0.6
\end{abstract}

Keywords: learning model; role playing; social interaction

\begin{abstract}
Abstrak
Penelitian ini dilakukan dengan tujuan menguji efektivitas penggunaan model pembelajaran role playing terhadap peningkatan interaksi sosial siswa kelas 4 SDN Bumiayu 2 Malang. Metode penelitian yang digunakan yaitu pre-experimental design dengan pendekatan kuantitatif. Hasil dari penghitungan uji paired sample test yang menunjukkan nilai signifikansi sebesar 0,000 yang bernilai kurang dari 0,05 . Sehingga dapat diartikan bahwa terdapat perbedaan yang signifikan antara hasil dari pretest dan posttest, dengan kata lain penggunaan model role playing berpengaruh dalam peningkatan interaksi sosial siswa. Tingkat efektivitas dari penggunaan model role playing termasuk dalam kategori sedang berdasarkan hasil uji N-Gain dengan rata-rata gain score sebesar 0,6.
\end{abstract}

Kata kunci: model pembelajaran; role playing; interaksi sosial

\section{Pendahuluan}

Pembelajaran Tatap Muka (PTM) saat ini sudah mulai dilaksanakan pada beberapa daerah yang telah memenuhi syarat tertentu yang telah diInstruksikan Menteri Dalam Negeri Nomor 38 Tahun 2021. PTM merupakan transisi dari pembelajaran daring yang sebelumnya telah diterapkan. Oleh karena itu, dalam pelaksanaan pembelajaran pada masa awal PTM tentunya berdampak pada pelaksanaan pembelajaran, baik dari segi pendidik maupun peserta didik. Rozi, dkk. (2020) menyebutkan bahwa ketidaksiapan psikologi dan pola belajar mengajar merupakan beberapa masalah yang dapat timbul pada masa transisi tersebut.

Berdasarkan hasil wawancara kepada wali kelas 4 SDN Bumiayu 2 Malang, diketahui bahwa pelaksanaan kegiatan pembelajaran pada masa awal PTM mempunyai kendala yang berkaitan dengan interaksi sosial siswa dan model pembelajaran. Interaksi sosial sendiri berkaitan dengan hubungan sosial oleh individu satu dengan individu lainnya, ataupun antar kelompok, serta terjadi timbal balik diantaranya (Zuhara, 2020). Kemampuan siswa dalam melakukan interaksi sosial tentunya tidaklah sama antar individu siswa. Terdapat empat 
indikator yang menunjukkan tingkat ketercapaian interaksi sosial, yaitu: (1) interaksi dan hubungan individu dengan kelompok; (2) Sikap dan tingkah laku dalam mengendalikan diri; (3) sikap sosial; dan (4) Pengelolaan emosi (Hurlock, 2013).

Selama pembelajaran daring, guru menerapkan model pembelajaran yang terbatas pada model pembelajaran konvensional seperti penugasan online dan ceramah virtual sehingga siswa tidak mempunyai waktu yang banyak untuk berinteraksi dengan teman sebayanya. Kondisi ini berlanjut hingga ditetapkannya PTM, meskipun siswa sudah kembali belajar di sekolah dan bertemu teman sebayanya akan tetapi tingkat interaksi sosial mereka cenderung minim. Minimnya interaksi selama pembelajaran memberikan dampak terhadap penggunaan model-model pembelajaran yang kurang bervariasi. Siswa sudah terlanjur nyaman dengan proses pembelajaran individu, dimana siswa hanya mendengarkan, memperhatikan penjelasan materi lalu mengerjakan tugas, dan hanya terjadi interaksi satu arah, yang menyebabkan siswa menjadi pasif dan bosan. Pada saat siswa kembali ke sekolah, mereka hanya saling menyapa menanyakan kabar tanpa ada interaksi yang lebih intens seperti belajar bersama atau kegiatan yang membutuhkan interaksi dalam waktu yang relatif lama.

Berdasarkan permasalahan transisi PTM tersebut, maka perlu diterapkannya sebuah model pembelajaran yang dapat membiasakan siswa terbiasa berinteraksi antusias dalam pembelajaran tatap muka yang sudah mulai dilaksanakan. Model interaksi sosial dapat menjadi salah satu pilihan dalam mengatasi permasalahan tersebut, dikarenakan model tersebut menekankan pada cara siswa dalam berinteraksi dengan lingkungan sosial di sekitarnya. Pembelajaran dengan menitikberatkan pada hubungan yang positif antar individu dengan individu, dan individu dengan kelompok sangat berdampak kepada pemahaman serta konsepsi terhadap siswa mengenai sikap dan perilaku yang harus dilakukannya saat berkomunikasi dengan orang lain. Melalui model pembelajaran interaksi sosial ini juga dapat membantu siswa dalam mengembangkan rasa kepercayaan diri, keterampilan sosial, berempati, serta bersimpati selama kegiatan pembelajaran berlangsung maupun dalam kehidupan sosial di masyarakat (Winata \& Hasanah, 2021).

Keaktifan berinteraksi siswa selama proses pembelajaran berkaitan juga dengan kurangnya kesempatan siswa dalam mengemukakan pendapat atau pemikirannya selama pembelajaran berlangsung. Hal tersebut mengakibatkan siswa hanya diam dan duduk mendengarkan serta mencatat saja, sehingga terkesan muncul rasa ketidakpedulian siswa terhadap pembelajaran yang berlangsung. Rasa ketidakpedulian tersebut dapat diatasi melalui pembelajaran dengan materi yang melibatkan siswa agar mampu berperan aktif partisipatif dalam pembelajaran (Sekali \& Tarigan, 2019).

Faktanya, proses Pembelajaran Tatap Muka (PTM) yang berlangsung di kelas 4 SDN Bumiayu 2 pada saat ini tengah mengalami masalah yang berkaitan dengan keaktifan siswa selama pembelajaran sehingga berpengaruh terhadap penurunan interaksi sosial siswa selama PTM berlangsung. Untuk mengatasi permasalahan tersebut, maka diperlukan penerapan model pembelajaran yang dapat memicu keaktifan siswa dan partisipatif pada saat proses pembelajaran sehingga dapat meningkatkan interaksi sosial siswa, seperti model interaksi sosial bermain peran. Role playing adalah salah satu jenis model pembelajaran dimana siswa dapat bermain pada skenario drama yang menekankan pada interaksi dalam setiap perannya.

Pada model ini, siswa berperan sebagai seseorang dengan profesi ataupun karakter tertentu, sehingga siswa dapat mempelajari makna dari tindakan yang dilakukan setiap tokoh 
dalam skenario drama tersebut (Nurgiansah, dkk., 2021). Model pembelajaran role playing membantu siswa dalam menemukan makna pribadi dalam kehidupan sosialnya sehingga mampu untuk memecahkan masalah sosial yang terjadi di lingkungan sekitar siswa. Model ini juga membantu siswa dalam bekerja sama menganalisis keadaan sosial sehingga dapat mengembangkan sikap demokratis dalam menghadapi dan menyelesaikan masalah (Bali, 2017).

Berdasarkan hasil dari penelitian terdahulu yang dilakukan Ari (2018) membuktikan bahwa penggunaan model role playing pada saat belajar menjadikan siswa lebih cakap dalam berinteraksi dengan siswa yang lain. Perubahan perilaku nampak pada aktivitas sosial siswa selama pembelajaran menggunakan model role playing. Meningkatnya kemampuan kerjasama, komunikasi, dan sikap saling menghargai antar siswa menjadi dampak yang dihasilkannya.

Model role playing atau bermain peran dapat digunakan pada saat proses pembelajaran untuk meningkatkan interaksi sosial antar siswa yang meliputi keberanian dalam tampil, aktif berpendapat, berinteraksi dengan teman sebaya, serta bereaksi positif selama pembelajaran berlangsung (Andriati, 2016). Berdasarkan penjabaran paparan masalah di atas, peneliti bermaksud untuk melihat efektivitas dari model pembelajaran role playing atau bermain peran terhadap peningkatan interaksi sosial siswa di kelas 4 SDN Bumiayu 2 Malang.

\section{Metode}

Desain penelitian yang digunakan pada penelitian ini yaitu metode pre-experimental design dengan pendekatan kuantitatif pada pelaksanaan penelitiannya. Penelitian ini menggunakan uji coba one group pretest dan posttest sehingga uji coba hanya dilakukan pada kelompok kelas eksperimen dan tidak memerlukan kelas kontrol sebagai pembanding. Adapun sampel penelitian yang sekaligus sebagai kelas eksperimen yaitu seluruh siswa kelas 4B SDN Bumiayu 2 dengan jumlah 24 siswa.

Instrumen pengumpulan data yang digunakan pada penelitian ini yaitu angket pretest dan angket posttest dengan skala likert. Hasil efektivitas penggunaan model role playing diperoleh dari uji paired sample t test dan uji $N$-Gain. Hasil pretest dan hasil posttest diuji normalitas dan homogenitasnya terlebih dahulu melalui SPSS, kemudian setelah itu dilakukan penghitungan uji paired sample test.

Uji normalitas dilakukan dengan teknik shapiro wilk dengan dasar keputusan diperoleh dari nilai signifikansi. Apabila nilai signifikansi $>0,05$ maka data tersebut dapat dikategorikan distribusi normal. Jika nilai signifikansi $<0,05$ data tidak berdistribusi secara normal. Begitu pula dengan uji homogenitas, didasarkan pada nilai signifikansi. Data homogen yaitu memiliki nilai signifikansi $>0,05$ dan apabila nilai signifikansi $<0,05$ maka data tidak homogen.

Setelah diketahui bahwa data berdistribusi normal, maka dilanjutkan dengan penghitungan pengaruh peningkatan hasil pretest dan posttest menggunakan uji paired sample test yang didasarkan pada nilai signifikansi. Apabila nilai signifikan $<0,05$ berarti terdapat beda yang signifikan antara hasil pretest dan hasil posttest, yang berarti penggunaan model role playing berpengaruh terhadap peningkatan interaksi sosial siswa. Apabila nilai signifikansi > 0,05 berarti tidak terdapat beda yang signifikan antara hasil setelah dilaksanakannya pretest dan posttest, yang berarti penggunaan model role playing dalam pembelajaran tidak berpengaruh terhadap peningkatan interaksi sosial siswa. 
Tingkat efektivitas penggunaan model role playing diukur melalui penghitungan $\mathrm{N}$-Gain dengan skor ideal 80. Tafsiran tingkat efektivitas gain skor menurut Hake (1999) yaitu, $g>0,7$ (tergolong tinggi); $0,3<\mathrm{g} \leq 0,7$ (tergolong sedang); dan $\mathrm{g} \leq 0,3$ (tergolong rendah).

\section{Hasil dan Pembahasan}

\subsection{Gambaran Interaksi Sosial Siswa}

Gambaran dari interaksi sosial siswa didasarkan pada indikator pada instrumen yang telah ditetapkan. Terdapat empat indikator yang menjadi acuan, antara lain (1) interaksi dan hubungan individu dengan kelompok; (2) Sikap dan tingkah laku dalam mengendalikan diri; (3) sikap sosial; dan (4) Pengelolaan emosi (Hurlock, 2013).

\subsubsection{Interaksi dan Hubungan Individu dengan Kelompok}

Berdasarkan indikator yang dijabarkan pada angket tentang interaksi dan hubungan antara kelompok dengan individu hasil pretest menunjukkan interaksi sosial siswa berada pada kategori rendah dengan jumlah 4 orang siswa. Sedangkan yang berada pada kategori tinggi sejumlah 20 orang siswa. Pada hasil posttest menunjukkan interaksi dan hubungan individu dengan kelompok berada pada kategori tinggi yaitu sejumlah 4 orang siswa dan untuk kategori sangat tinggi sejumlah 20 siswa. Penjabaran dari hasil pretest tersebut secara rinci dapat dilihat pada Tabel 1.

Tabel 1. Interaksi dan Hubungan Individu dengan Kelompok

\begin{tabular}{cccc}
\hline \multirow{2}{*}{ Interval } & \multicolumn{2}{c}{ Frekuensi } & \multirow{2}{*}{ Kategori } \\
\cline { 2 - 3 } & Pretest & Posttest & \\
\hline $4-6$ & 0 & 0 & Sangat Rendah \\
$7-10$ & 4 & 0 & Rendah \\
$11-13$ & 20 & 4 & Tinggi \\
$14-16$ & 0 & 20 & Sangat Tinggi \\
\hline
\end{tabular}

Berdasarkan perbandingan antara hasil dari pretest dan hasil dari posttest pada Tabel 1 diatas, terlihat bahwa terdapat peningkatan hasil interaksi dan hubungan individu dengan kelompok. Peningkatan tersebut menunjukkan hasil dari penggunaan model role playing dalam terhadap peningkatan interaksi sosial siswa. Melchioriyusni, dkk. (2013) yang menyebutkan bahwa interaksi sosial akan terbentuk dari interaksi yang terjadi antara siswa dengan kelompok atau teman sebayanya dimana pada interaksi yang terjadi tersebut juga akan mempengaruhi interaksi siswa antar individu, individu dengan kelompok, dan antar kelompok

\subsubsection{Sikap dan Tingkah Laku dalam Mengendalikan Diri}

Berdasarkan indikator sikap dan tingkah laku dalam mengendalikan diri, hanya satu orang siswa yang menunjukkan kategori rendah dalam interaksinya. Sedangkan yang termasuk dalam kategori tinggi sejumlah 23 siswa. Pada hasil posttest menunjukkan interaksi sosial siswa yang tergambar pada indikator sikap dan tingkah laku dalam mengendalikan diri berada pada kategori tinggi hanya satu orang siswa dan sejumlah 23 siswa di kategori sangat tinggi. Penjabaran gambaran tersebut dipaparkan rinci dan dapat dilihat pada Tabel 2. 
Tabel 2. Sikap dan Tingkah Laku dalam Mengendalikan Diri

\begin{tabular}{cccc}
\hline \multirow{2}{*}{ Interval } & \multicolumn{2}{c}{ Frekuensi } & \multirow{2}{*}{ Kategori } \\
\cline { 2 - 3 } & Pretest & Posttest & \\
\hline $7-11,25$ & 0 & 0 & Sangat Rendah \\
$12,25-16,5$ & 1 & 0 & Rendah \\
$17,5-21,75$ & 23 & 1 & Tinggi \\
$22,75-28$ & 0 & 23 & Sangat Tinggi \\
\hline
\end{tabular}

Berdasarkan perbandingan antara hasil pretest dan hasil posttest pada Tabel 2 diatas, terlihat bahwa terdapat peningkatan hasil sikap dan tingkah laku dalam mengendalikan diri. Peningkatan tersebut menunjukkan hasil dari penggunaan model role playing dalam terhadap peningkatan interaksi sosial siswa. Zulfah (2021) menjelaskan bahwa kemampuan pengendalian diri merupakan kemampuan seseorang mengendalikan sikap dan tingkah lakunya dengan memikirkan secara baik-baik situasi tertentu agar dapat diterima oleh lingkungan sosialnya, serta berdampak positif dalam peningkatan interaksi dan hubungan sosial di lingkungannya tersebut.

\subsubsection{Sikap Sosial}

Interaksi sosial yang tergambar dalam indikator sikap sosial sesuai hasil pretest menunjukkan bahwa sejumlah 9 orang siswa yang termasuk dalam kategori rendah. Sedangkan 15 orang siswa lainnya termasuk dalam kategori tinggi. Pada hasil posttest menunjukkan interaksi sosial siswa yang tergambar dalam indikator sikap sosial, sejumlah 8 orang siswa menempati kategori tinggi dan pada kategori sangat tinggi sejumlah 16 siswa. Penjabaran gambaran tersebut dapat dilihat secara rinci pada Tabel 3.

Tabel 3. Sikap Sosial

\begin{tabular}{cccc}
\hline \multirow{2}{*}{ Interval } & \multicolumn{2}{c}{ Frekuensi } & \multirow{2}{*}{ Kategori } \\
\cline { 2 - 3 } & Pretest & Posttest & \\
\hline $4-6$ & 0 & 0 & Sangat Rendah \\
$7-10$ & 9 & 0 & Rendah \\
$11-13$ & 15 & 8 & Tinggi \\
$14-16$ & 0 & 16 & Sangat Tinggi \\
\hline
\end{tabular}

Berdasarkan perbandingan antara hasil pretest dan posttest pada Tabel 3, menunjukkan bahwa terdapat peningkatan hasil sikap sosial. Peningkatan tersebut menunjukkan hasil dari penggunaan model role playing dalam terhadap peningkatan interaksi sosial siswa. Bali (2017) menjelaskan bahwa sikap sosial dan perilaku sosial turut serta menjadi faktor penting dalam pengembangan keterampilan sosial yang berhubungan dengan kemampuan yang dimiliki siswa pada saat berinteraksi dengan seseorang di sekitarnya.

\subsubsection{Pengelolaan Emosi}

Tergambarkan bahwa interaksi sosial pada hasil pretest indikator pengelolaan emosi, yang tergolong dalam kategori tinggi sejumlah 22 orang siswa. Sedangkan 2 siswa lainnya tergolong pada tingkat sangat tinggi. Pada hasil posttest tergambar bahwa keseluruhan siswa 
yaitu sejumlah 24 orang siswa tergolong pada kategori sangat tinggi pada indikator pengelolaan emosi. Perolehan hasil Pretest dan Posttest dapat dilihat pada Tabel 4.

Tabel 4. Pengelolaan Emosi

\begin{tabular}{cccc}
\hline \multirow{2}{*}{ Interval } & \multicolumn{2}{c}{ Frekuensi } & \multirow{2}{*}{ Kategori } \\
\cline { 2 - 3 } & Pretest & Posttest & \\
\hline $5-7,75$ & 0 & 0 & Sangat Rendah \\
$8,75-11,5$ & 0 & 0 & Rendah \\
$12,5-15,25$ & 22 & 0 & Tinggi \\
$16,25-20$ & 2 & 24 & Sangat Tinggi \\
\hline
\end{tabular}

Berdasarkan perbandingan dari hasil pretest dan hasil posttest yang dijabarkan pada Tabel 4, menunjukkan bahwa terdapat peningkatan hasil pengelolaan emosi. Peningkatan tersebut menunjukkan hasil dari penggunaan model role playing dalam terhadap peningkatan interaksi sosial siswa. Lingga (2017) menjelaskan bahwa dalam proses interaksi sosial siswa pada lingkungan sekitarnya, kematangan emosi menjadi faktor penting dalam upaya penyesuaian diri anak dengan lingkungan sosialnya. Apabila tingkat kematangan emosi siswa rendah, maka interaksi sosialnya juga akan rendah pula, yang mengakibatkan siswa kesulitan saat beradaptasi di lingkungan sekitarnya.

\subsection{Keefektifan Penggunaan Model Role playing untuk Meningkatkan Interaksi Sosial Siswa}

Sebelum dilakukan analisis data mengenai efektivitas penggunaan model role playing perlu dilakukan pengujian prasyarat yaitu uji normalitas dan homogenitas.

\subsubsection{Uji Normalitas}

Uji normalitas dilakukan menggunakan teknik shapiro wilk dengan bantuan SPSS dengan hasil seperti dalam Tabel 5 berikut ini.

Tabel 5. Hasil Uji Normalitas

\begin{tabular}{lcccccc}
\hline & \multicolumn{3}{c}{ Kolmogorov-Smirnova } & \multicolumn{3}{c}{ Shapiro-Wilk } \\
\cline { 2 - 7 } & Statistic & df & Sig. & Statistic & df & Sig. \\
\hline Pretest & .143 & 24 & .200 & .963 & 24 & .499 \\
Posttest & .184 & 24 & .035 & .961 & 24 & .466 \\
\hline
\end{tabular}

Jika dilihat pada Tabel 5, Hasil pretest memiliki nilai signifikansi 0,499 artinya nilai lebih dari 0,05 . Hasil normalitas posttest bernilai signifikansi 0,466 yang berarti nilainya lebih dari 0,05 . Kesimpulannya, data pretest dan posttest berdistribusi dengan normal dan dapat dilakukan analisis menggunakan statistik parametrik yaitu uji paired sample test.

\subsubsection{Uji Homogenitas}

Data hasil pretest dan posttest kemudian diuji homogenitas menggunakan one way anova melalui SPSS dengan hasil pada Tabel 6 berikut ini. 
Tabel 6. Hasil Uji Homogenitas

\begin{tabular}{llll}
\hline Levene Statistic & df1 & df2 & Sig. \\
\hline .578 & 1 & 46 & .451 \\
\hline
\end{tabular}

Berdasarkan Tabel 6, dapat diketahui bahwa homogenitas bernilai signifikansi sebesar 0,451 berarti nilainya lebih dari 0,05 . Kesimpulannya, data hasil pretest dan hasil posttest bersifat homogen.

\subsubsection{Uji Paired Sample Test}

Untuk mengetahui pengaruh penerapan model role playing terhadap peningkatan interaksi sosial siswa, dilakukan uji paired sample test melalui SPSS. Hasil penghitungan dijabarkan pada Tabel 7 berikut ini.

Tabel 7. Hasil Uji Paired Sample Test

\begin{tabular}{|c|c|c|c|c|c|c|c|c|}
\hline & \multicolumn{5}{|c|}{ Paired Differences } & \multirow{3}{*}{$\mathbf{t}$} & \multirow{3}{*}{ df } & \multirow{3}{*}{$\begin{array}{l}\text { Sig. (2- } \\
\text { tailed) }\end{array}$} \\
\hline & \multirow[t]{2}{*}{ Mean } & \multirow[t]{2}{*}{$\begin{array}{c}\text { Std. } \\
\text { Deviation }\end{array}$} & \multirow{2}{*}{$\begin{array}{l}\text { Std. } \\
\text { Error } \\
\text { Mean }\end{array}$} & \multicolumn{2}{|c|}{$\begin{array}{l}\text { 95\% Confidence } \\
\text { Interval od the } \\
\text { Difference }\end{array}$} & & & \\
\hline & & & & Lower & Upper & & & \\
\hline $\begin{array}{l}\text { Pair } 1 \\
\text { (pretest- } \\
\text { posttest) }\end{array}$ & -14.417 & 2.933 & .599 & -15.655 & -13.179 & -24.082 & 23 & .000 \\
\hline
\end{tabular}

Berdasarkan Tabel 7, nilai signifikansi dari hasil uji paired sample test yaitu 0,000 berarti nilainya kurang dari 0,05. Dapat disimpulkan bahwa terdapat perbedaan yang signifikan antara hasil dari pretest dan hasil posttest, dengan kata lain penggunaan model role playing berpengaruh dalam peningkatan interaksi sosial siswa.

\subsubsection{Uji N-Gain}

Tingkat efektivitas penggunaan model role playing berpengaruh dalam peningkatan interaksi sosial siswa diukur melalui uji $N$-Gain. Hasil penghitungan $N$-Gain terinci pada Tabel 8.

Tabel 8. Hasil Uji N-Gain

\begin{tabular}{ccccc}
\hline No & Nama Siswa & Hasil Pretest & Hasil Postest & Gain Score \\
\hline 1 & S-1 & 57 & 72 & 0.7 \\
2 & S-2 & 58 & 69 & 0.5 \\
3 & S-3 & 60 & 68 & 0.4 \\
4 & S-4 & 55 & 68 & 0.5 \\
5 & S-5 & 57 & 71 & 0.6 \\
6 & S-6 & 50 & 72 & 0.7 \\
7 & S-7 & 52 & 71 & 0.7 \\
8 & S-8 & 61 & 74 & 0.7 \\
9 & S-9 & 56 & 67 & 0.5 \\
10 & S-10 & 57 & 71 & 0.6 \\
11 & S-11 & 55 & 71 & 0.6
\end{tabular}




\begin{tabular}{lcccc}
\hline No & Nama Siswa & Hasil Pretest & Hasil Postest & Gain Score \\
\hline 12 & S-12 & 57 & 74 & 0.7 \\
13 & S-13 & 54 & 71 & 0.7 \\
14 & S-14 & 57 & 70 & 0.6 \\
15 & S-15 & 55 & 69 & 0.6 \\
16 & S-16 & 56 & 66 & 0.4 \\
17 & S-17 & 59 & 71 & 0.6 \\
18 & S-18 & 58 & 68 & 0.5 \\
19 & S-19 & 55 & 73 & 0.7 \\
20 & S-20 & 52 & 70 & 0.6 \\
21 & S-21 & 56 & 73 & 0.7 \\
22 & S-22 & 52 & 72 & 0.7 \\
23 & S-23 & 56 & 72 & 0.7 \\
24 & S-24 & 60 & 69 & 0.5 \\
Rata-rata Gain Score & & & 0.6 \\
\hline
\end{tabular}

Berdasarkan paparan hasil uji N-Gain pada Tabel 8, bisa dilihat bahwa rata-rata gain score sebesar 0,6. Jadi, dapat disimpulkan bahwa tingkat efektivitas dari penggunaan model role playing berpengaruh dalam peningkatan interaksi sosial siswa berada pada kategori sedang.

\section{Simpulan}

Hasil analisis yang dilakukan pada penelitian ini, bisa disimpulkan model pembelajaran role playing terbukti efektif dalam peningkatan interaksi sosial siswa kelas 4 . Hasil tersebut dibuktikan dengan hasil dari penghitungan uji paired sample test dengan nilai signifikansi 0,000 yang berarti kurang dari 0,05 , sehingga terdapat perbedaan yang signifikan antara hasil pretest dan hasil posttest, yang berarti penggunaan model role playing berpengaruh dalam peningkatan interaksi sosial siswa. Tingkat efektivitas memiliki hasil dari uji $\mathrm{N}$-Gain dengan rata-rata gain score sebesar 0,6 dan masuk pada kategori sedang.

\section{Daftar Rujukan}

Andriati, N. (2016). Model Bimbingan Kelompok Dengan Teknik Bermain Peran Untuk Meningkatkan Interaksi Sosial Siswa. Jurnal Konseling Gusjigang, 2(2), 125-132. https://doi.org/10.24176/ikg.v2i2.698

Ari, H. (2018). Penerapan Role Playing untuk Meningkatkan Kemampuan Interaksi Sosial Siswa Kelas 5 SDN Kuin Utara 7 Banjarmasin. Tesis. Malang: Universitas Negeri Malang. http://repository.um.ac.id/id/eprint/63253

Bali, M. M. E. I. (2017). Model Interaksi Sosial dalam Mengelaborasi Keterampilan Sosial. Jurnal Pedagogik, 4(2), 211-227. https://doi.org/10.33650/pjp.v4i2.19

Hake, R. R. (1999). Analyzing Change/Gain Scores. https://www1.physics.indiana.edu/ sdi/AnalyzingChangeGain.pdf

Hurlock, E. B. (2013). Perkembangan Anak, jilid 1. Jakarta: Erlangga.

Instruksi Menteri Dalam Negeri Nomor 38 Tahun 2021 tentang Pemberlakuan Pembatasan Kegiatan Masyarakat Level 4, Level 3, dan Level 2, Corona Virus Disease 2019 Di Wilayah Jawa dan Bali. (online). (https://malangkota.go.id/2021/08/31/inmendagri-nomor-38-tahun-2021-tentan g-ppkm-level-4level-3-dan-level-2-covid-19-di-jawa-dan-bali/), diakses 22 September 2021.

Lingga, Z. (2017). Hubungan Kematangan Emosi dan Interaksi Sosial dengan Penyesuaian Diri Siswa MTsN Kabanjahe Kabupaten Karo. Jurnal ANSIRU PAI, 1(2), 57-66. http://dx.doi.org/10.30821/ansiru.v1i2.1513.g1240

Melchioriyusni, dkk. (2013). Interaksi Sosial Siswa dengan Kelompok Teman Sebaya di Sekolah dan Implikasinya terhadap Pelayanan BK. Jurnal Konseling dan Pendidikan, 1(2), 102-108. https://doi.org/10.29210/11700 
Jurnal Pembelajaran, Bimbingan, dan Pengelolaan Pendidikan, 1(11), 2021, 888-896

Nurgiansah, T. H, dkk. (2021). Role playing dalam Pembelajaran Pendidikan Pancasiladan Kewarganegaraan. Jurnal Kewarganegaraan, 56-64. https://jurnal.unimed.ac.id/2012/index.php/ik/article/view/22597

Rozi, dkk. (2020). Penerapan Adaptasi Kebiasaan Baru pada Era Pandemi Virus Corona 19 di Berbagai Sektor Pendidikan. Tulungagung: Akademia Pustaka.

Sekali, E. B. K. \& Tarigan, M. A. (2019). Pengaruh Interaksi Sosial Terhadap Hasil Belajar. Prosiding Seminar Nasional Fakultas Ilmu Sosial Universitas Negeri Medan, 3, 794-797. http://digilib.unimed.ac.id/id/eprint/39420

Winata, K. A. \& Hasanah, A. (2021). Implementasi Model Pembelajaran Interaksi Sosial Untuk Meningkatkan Karakter Peserta Didik. Jurnal Pendidikan, 9(1), 22-32. https://doi.org/10.36232/pendidikan.v9i1.639

Zuhara, E. (2020). Efektivitas Konseling Kelompok dengan Teknik Modeling untuk Meningkatkan Interaksi Sosial Siswa. Jurnal EDUKASI (Mesia Kajian Bimbingan Konseling), 6(1), 41-57. http://dx.doi.org/10.22373/je.v6i1.8208

Zulfah. (2021). Karakter: Pengendalian Diri. IQRA : Jurnal Pendidikan Agama Islam, 1(1), 28-33. https://journal.unismuh.ac.id/index.php/iqra/article/view/5803 